\title{
Tree mortality in a mixed deciduous forest in Northwestern Russia over 22 years
}

\author{
Igor DROBYSHEV $^{1 *}$, Alexander DobRovolsKY ${ }^{2,3}$, Vasiliy NESHATAEV ${ }^{2}$ \\ ${ }^{1}$ Southern Swedish Forest Research Centre, P.O. Box 49, SLU, Alnarp, 23053, Sweden \\ ${ }^{2}$ St. Petersburg State Forest Technical Academy, Institutsky str. 5, St. Petersburg, 194021, Russia \\ ${ }^{3}$ Canada Research Chair in Ecology and Sustainable Forest Management, University of Québec in Abitibi-Témiscamingue, \\ 445 blvd. de l'Université, Rouyn-Noranda, QC, J9X5E4 Canada
}

(Received 26 May 2008; accepted 19 November 2008)

Keywords: European hardwoods / conservation / forest decline / crown condition / forest inventory
Mots-clés :

feuillus européens /

conservation /

dépérissement des forêts /

état du houppier /

inventaire forestier

\begin{abstract}
- We studied mortality rates of birch, small-leaved linden, pedunculate oak, Norway maple, black alder, common ash and Norway spruce, assessed through two inventories of 12664 trees in the unmanaged mixed deciduous forests of Oranienbaum Park, northwestern Russia, in 1981 and 2003.

- Our objectives were to evaluate if (a) long-term mortality rates vary among species, and if (b) crown condition, age and tree size affect the probability of mortality.

- Over this period, tree mortality rates in the park varied annually from 1 to $3 \%$ for healthy and moderately healthy trees, and from 3.9 to $9.3 \%$ for declining trees. The lowest mortality rates were observed for small-leaved linden and oak ( 0.8 and $1.0 \%$, respectively), and the highest rate for birch $(2.7 \%)$. We found (1) a significant and consistent association between tree condition and the probability of mortality, and (2) significantly higher mortality rates in smaller trees of ash, maple and oak.

- The effect of species-specific biology on mortality rates in the Oranienbaum Park was largely overridden by the "health status" and environmental conditions of the trees (e.g. degree of crown shading). The observed rates were similar to the estimates from natural temperate deciduous forests in both Europe and North America, indicating similar intensity of mortality in these ecosystems under natural conditions.
\end{abstract}

Résumé - Mortalité des arbres dans une forêt feuillue mixte du nord-ouest de la Russie pendant 22 ans.

- Nous avons étudié les taux de mortalité du bouleau, du tilleul à petites feuilles, du chêne pédonculé, de l'érable plane, de l'aulne, du frêne commun, et de l'épicéa par le biais de deux inventaires concernant 12664 arbres, en 1981 et 2003, dans les forêts mixtes non gérées de l'Oranienbaum Park, dans le nord-ouest de la Russie.

- Nos objectifs étaient d'évaluer si (a) à long terme les taux de mortalité varient selon les espèces, et si (b) l'état du houppier, l'âge et la taille des arbres affectent la probabilité de mortalité.

- Au cours de cette période, les taux de mortalité des arbres dans le parc ont varié annuellement de 1 à $3 \%$ pour les arbres sains et modérément sains, et de 3,9 à 9,3\% pour les arbres dépérissants. Les taux de mortalité les plus bas ont été observés pour le tilleul à petites feuilles et le chêne (respectivement $0,8$ et $1,0 \%)$ et le taux le plus élevé pour le bouleau $(2,7 \%)$. Nous avons trouvé (1) une importante et constante association entre la condition de l'arbre et la probabilité de mortalité, et (2) les taux de mortalité significativement les plus élevés chez les plus petits arbres chez le frêne, l'érable et le chêne.

- Les effets biologiques de l'espèce sur les taux de mortalité ont été en grande partie annulés par l'état de santé des arbres et les conditions environnementales (par exemple le degré d'ombrage de la couronne). Les taux observés étaient similaires aux estimations obtenues pour les forêts naturelles tempérées en Europe et en Amérique du Nord, indiquant une intensité similaire de mortalité dans ces écosystèmes en conditions naturelles.

\footnotetext{
*Corresponding author: Igor.Drobyshev@ess.slu.se
} 


\section{INTRODUCTION}

Mortality of canopy trees is an important driver of forest dynamics (Franklin et al., 1987). The canopy tree's susceptibility to a mortality factor (e.g. high wind) may vary considerably as a result of species strategy (e.g. rooting depth, residence time in the canopy and light requirements), which is adapted to a particular set of ecological conditions (e.g. frequency of high wind episodes, canopy composition). Knowledge of mortality rates and their variation among species in a forest community is essential for modeling tree population and ecosystem dynamics (Monserud and Sterba, 1999; Pacala et al., 1996), understanding forest successional trajectories (Wolf et al., 2004), and providing sound advice for forest management (Bobiec, 2002; Peterson and Ryan, 1986; Zhao et al., 2004).

In the deciduous forests of the temperate zone, tree mortality due to aging and competition interacts with natural disturbance factors such as wind, fire and insect outbreaks (Lemieux and Filion, 2004; Runkle, 2000; Suarez et al., 2004). This results in a generally irregular pattern of tree removal from the canopy, periods of low mortality being intermixed with episodes of environmental stresses and disturbance events leading to higher rates of tree removal from the canopy. Due to such temporal variation in the mortality rates, our confidence in empirically-obtained mortality rates increases with the length of the period covered by a study. Therefore, in shortterm $(<10 y)$ studies of mortality rates, both the actual timing of a study and the length of the observed period may be essential in interpreting the study results. Mortality studies covering a period of several decades may be a better proxy for long-term rates, integrating over a range of mortality-related factors and presenting a valuable indicator of species population dynamics (Ford and Brooks, 2002; Pedersen, 1998; 1999; Suarez et al., 2004).

Averaged over decade-long periods, tree mortality rates in closed-canopy forests have been shown to be consistent across a wide range of ecosystems. A review of mortality rates across a range of old-growth temperate, boreal and tropical forests suggested that they typically vary within $0.5-3 \%$ annually (Peterken, 1996). Tree mortality rates in Eastern deciduous forest of North America were found to be $0.5-2 \%$ (Lin et al., 2004; Runkle, 1982). An analysis of European monitoring data reveals that the annual mortality rate of different tree species in Europe varied between 0.1 and $0.8 \%$, and that the mean annual mortality was higher for young trees (Lorenz et al., 2000). Rates in the range of 0.1 and $1 \%$ were obtained in a number of European studies utilizing primarily forest inventory datasets (Monserud and Sterba, 1996; Ozolincius et al., 2005).

Natural tree mortality is well approximated by Poisson distribution, which is a suitable model for the occurrence of events observed over a fixed period of time. Due to the nature of this distribution, both the length of the observation period and the sample size are crucial to provide solid estimates of long-term mortality rates. Despite a number of recently published datasets (Blomberg et al., 2004; Monserud and Sterba, 1999; Ozolincius et al., 2005; Tuhus, 1997; Wolf et al., 2004), our knowledge on natural mortality rates of main tree species in European natural deciduous forests remains limited. The most replicated published datasets are mostly based on managed forest stands, the respective rates therefore integrating the effects of natural processes and silvicultural activities. European natural mixed forests in nemoral and hemiboreal zones are poorly studied in this respect, which is partly explained by the scarcity of stands escaping human interventions (Niklasson and Nilsson, 2005). Mortality rates obtained for canopy trees in this bioclimatic region (Drobyshev et al., 2007b; Wolf et al., 2004) have been derived from comparatively small datasets, which may question the general nature of the results.

The current study is intended to partly fill this gap and provide mortality rates based on a highly replicated and detailed dataset originating from two inventories of semi-natural mixed deciduous forests of Oranienbaum Park, St. Petersburg region, northwestern Russia, conducted over a 22-year period (19812003). The main goal of the study was to assess the current mortality rates of main canopy trees and to evaluate their variation across species, tree condition and size classes. We put forward two hypotheses:

(1) Long-term mortality rates vary among species due to differences in species strategies (early- vs. late-successional species), and associated differences in the average residence time in the canopy;

(2) Crown condition, age and tree size affect the probability of mortality and these effects hold across all tree species studied.

Finally, we consider the reported mortality rates in wider ecological and management contexts and compare speciesspecific mortality rates observed in the Oranienbaum Park with the rates reported in other European studies. For this purpose, we utilize data from four recent studies conducted in different parts of the European sub-continent (Monserud and Sterba, 1999; Ozolincius et al., 2005; Tuhus, 1997; Wolf et al., 2004). All these studies covered time periods of at least ten years and were well replicated (> 1000 trees in a single study).

\section{STUDY AREA: THE ORANIENBAUM PARK}

Oranienbaum $\operatorname{Park}^{1}\left(59^{\circ} 55^{\prime} \mathrm{N}, 2^{\circ} 45^{\prime} \mathrm{E}\right)$ is located on the southern coast of the Gulf of Finland, $40 \mathrm{~km}$ west of St. Petersburg, NW Russia. The climate of the area is moderately continental. The average temperature of July, the warmest month, is $17.9^{\circ} \mathrm{C}$, and the average temperature of January, the coldest month, is $-7.9^{\circ} \mathrm{C}$ (WMO, 2008). The known temperature maximum for the area of the park is $+35^{\circ} \mathrm{C}$, and the minimum is $-50{ }^{\circ} \mathrm{C}$. Spring frosts can occur as late as in the first 10 days of June and frosts at the end of the growing season can be observed as early as in the last decade of August. The long-term average of annual precipitation is $725 \mathrm{~mm}$. The amount of precipitation is the lowest during the winter period $(335 \mathrm{~mm})$, and the greatest - during May - September (390 mm).

\footnotetext{
${ }^{1}$ See the short history of the Park, Appendix B, available on line at www.afs-journal.org
} 
The relief of the park is a terraced plain, located between the Baltic-Ladoga glint and the shoreline of the Gulf of Finland. Two terraces are situated at altitudes of $0-9 \mathrm{~m}$ and $16-$ $20 \mathrm{~m}$ a.s.l. The lower terrace with its slope facing the Gulf of Finland occupies the main part of the park. Hydrological features of the terrain, including the river Karast, ponds and channels, occupy 9.3\% (15 ha) of the total park area (Maximov et al., 1982). The climatic and geological features of the territory promote mesophytic soil conditions. Moor-humus gley and gleyic soils on loam moraine dominate (Pestryakov, 1973). Soil data collected during the last inventory indicate that the soils of the park are not acidified: $\mathrm{pH}$ of the soil (as determined in the water solution) at the depth of 0 to $30 \mathrm{~cm}$ is centered around 6.0 and conductivity varies between 355.3 and $452.9 \mu \mathrm{S}$ (Dobrovolsky, unpublished data).

Deciduous stands with small-leaved linden (Tilia cordata Mill.), pedunculate oak (Quercus robur L.) and Norway maple (Acer platanoides L.) dominate the forests of the park. Other common tree species in the park include Norway spruce (Picea abies (L.) H. Karst), common ash (Fraxinus excelsior L.), black alder (Alnus glutinosa (L.) Gaertner) and downy birch (Betula pubescens Ehrh.). Most of the existing forest stands were planted during the establishment of the park in the second half of the 18th and the first half of the 19th centuries (Maximov et al., 1982). Today, the majority of the stands $(70 \%)$ are one to three ha in size and composed of pure or mixed deciduous forest. The total area of the park is $161 \mathrm{ha}$, of which 124 ha are forested. The total standing volume in the studied forests varied between 10 and $400 \mathrm{~m}^{3} \cdot \mathrm{ha}^{-1}$, with typical values being within $100-220 \mathrm{~m}^{3} \cdot \mathrm{ha}^{-1}$.

According to the Braun-Blanquet classification system, the major part of the vegetation cover in the park is represented by three forest types: Tilietum nemoriherbosum, Tilietum oxalidosum and Tilietum oxalidoso-filipendulosum. Tilietum nemoriherbosum occurs on loam well-drained fertile soils. Aegopodium podagraria predominates in the herb layer of this forest type. Tilietum oxalidosum occurs on generally similar sites with a thinner humus layer. Oxalis acetosella, $\mathrm{Ga}$ leobdolon luteum and Melica nutans are abundant in the herb layer of this type. Tilietum oxalidoso-filipendulosum is common on slightly moist fertile soils, with abundant Filipendula ulmaria and Oxalis acetosella in the herb layer.

\section{MATERIAL AND METHODS}

\subsection{The inventories and field sampling}

This study is based on data obtained during two inventories of the park vegetation, conducted in 1981 and in 2003. During the first inventory in 1981, data on more than 100000 single shrubs and trees were collected. For our analysis, we only selected trees which (1) were equal to or larger than $4 \mathrm{~cm}$ dbh in 1981, (2) had been mapped during the 1981 inventory and successfully located again in 2003, and (3) were not subject to pruning during 1981-2003. All of the 12664 trees were included in the analyses. Stands with mapped trees were regularly distributed across the territory of the park, which made it possible to assume that the sampled tree population may be considered representative of the whole forested vegetation of the park. We selected the seven most common tree species in the park for analysis: common ash, black alder, downy birch, small-leaved linden, Norway maple, pedunculate oak and Norway spruce. These seven species were represented by 11264 trees. Additionally, we obtained mortality estimates for other less common tree species in the park (total $n=1440$ ). This data is presented in the Appendix A (available on line at www.afs-journal.org) only and not discussed in the current paper. In all cases, only previously inventoried trees $(n=11264)$ and no new recruits were included in the 2003 inventory.

The following tree parameters were recorded: tree species, $\mathrm{DBH}$, condition class, degree of crown shading and tree age. The following four condition classes were used: 1 , indicating a healthy tree with a well-developed crown and no visible damage to the crown or the main stem (e.g. mechanical damage, presence of fungi or frost cracks); 2, indicating a tree with an underdeveloped and/or asymmetrical or lopsided crown, and/or with presence of fungi bodies on the main stem and/or frost holes; 3 , indicating a tree with a heavily underdeveloped or reduced crown commonly with the presence of fungi bodies and cracks, and 4, indicating a dead snag.

For each tree, we estimated crown shading, i.e. the proportion of tree crown which was not overtopped by tree crowns of neighboring trees. The crown of each inventoried tree was mapped in the field and crowns' juxtaposition between focal and neighboring trees was analyzed on the map (Fig. 1). Trees for which mapping did not provide a conclusive answer about their relative crown position were revisited in the field to assess directly the degree of crown shading (350 trees, $2.5 \%$ of all trees analyzed). Originally, crown shading was assessed as the portion of crown overtopped by other trees with the range of 0 to 1 , where 0.0 was a solitary tree growing in the open and 1.0 was a completely overtopped tree. For the analyses, crown shading was converted into three classes $(<0.33,0.34-0.66$ and $>0.67)$. Crown shading was assessed during the 1981 inventory only. This estimate was considered as a proxy for stand density on the tree scale. Tree age was visually assessed for each tree. To validate visual estimates, 30 to 40 trees of each species were cored with an increment borer at the ground level and age was estimated through ring counting during the initial inventory in 1981. During that inventory estimation of the tree age and coring were done in an interactive fashion, and the results of this estimation were generally well supported by the available planting dates of approximately 150 trees, obtained from historical archives. No permission for coring was obtained for the most recent inventory. However, comparison with available planting records suggests that error in the age estimation did not exceed 10-20 years in the majority of cases. To address the issue with visual age estimation, we did not use age as a variable, but utilized DBH (which correlated with the age estimates) and considered it as a grouping variable with only two classes (see below).

\subsection{Statistical methods}

Mortality rates were calculated as:

Annual mortality rate $=1-\left(C / N_{0}\right)^{1 / y}$, where $C$ was the number of currently recorded living trees, $N_{0}$ - original number of living trees and $y$ - number of years between resamples (22 y, in our study).

The association between the mortality rate and tree- and standlevel variables was analyzed through General Discriminant Analysis (Klecka, 1980). This analysis identifies dependences between an independent categorical variable (binary in our case, living vs. dead 

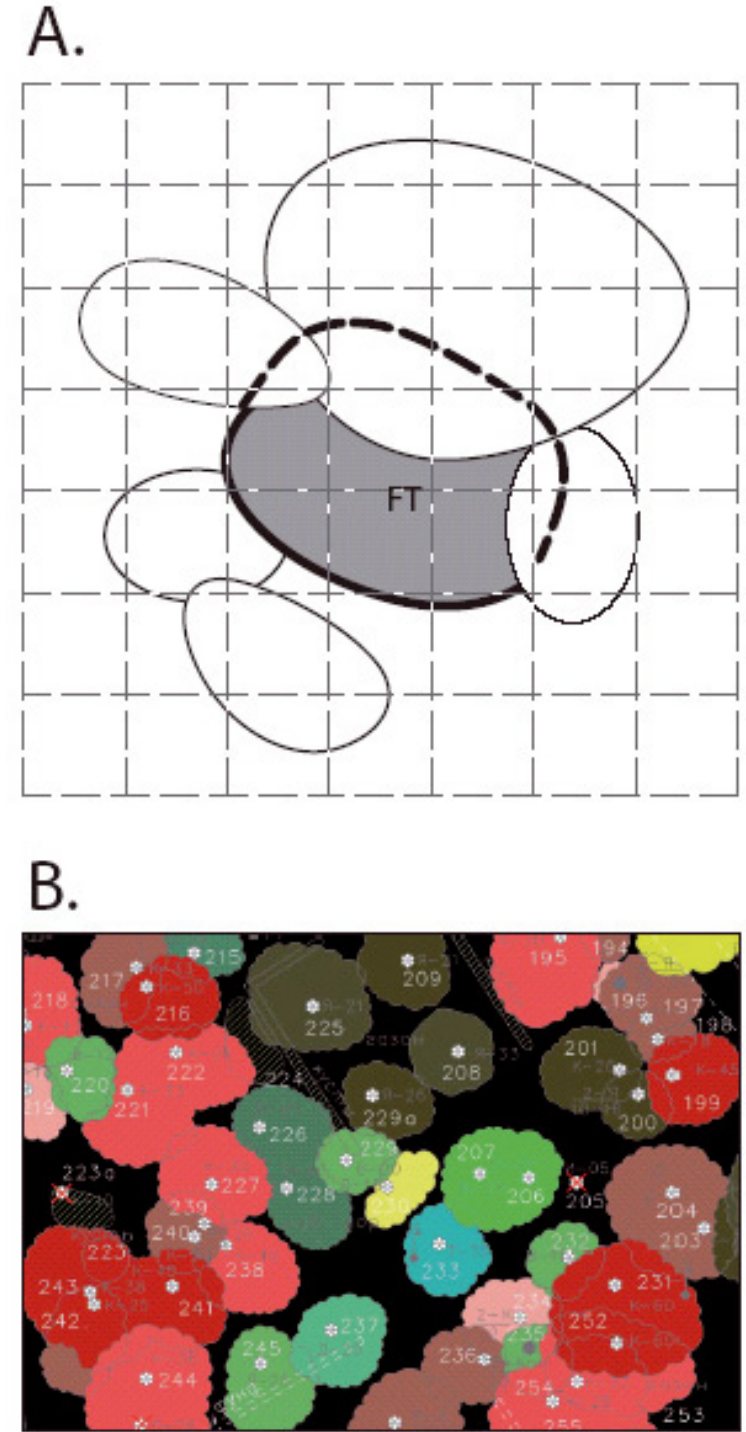

Figure 1. Determination of the crown shading. Projections of each tree were mapped and crown overlap was assessed with the help of a juxtaposed grid. A. An example of a focal tree (FT) classified into the 2 nd crown shading class. B. A part of the actual map used for the analyses.

tree) and categorical and/or continuous independent variables. Significance of independent variables indicates that knowledge of such variables improves the posterior classification probability for the dependent variable of interest, i.e. probability of mortality for the tree in the statistical model. In our analysis, we operated with categorical independent variables only. They were tree condition class, DBH and crown shading. Condition class was classified into three original condition classes for the living trees, as used during the 1981 inventory (see previous sub-section). Due to a generally low number of trees in the condition class 3, recorded during the inventory in 1981, these trees were not used in the discriminant analysis. This decision resulted in a decrease in the Type I error (rejecting true $\mathrm{H}_{0}$ ), and an increase in the Type II error (accepting false $\mathrm{H}_{0}$ ). In our study, due to the subjective estimation procedures used to assess tree conditions,
Table I. Descriptive statistics for the Oranienbaum Park inventory dataset. Crown shading is a 1981 inventory estimate. Age and DBH are 2003 inventory estimates.

\begin{tabular}{lccc}
\hline Species & $\begin{array}{c}\text { Classes of crown shading, } \\
\text { \% of each class }\end{array}$ & $\begin{array}{c}\text { Age, } \\
\text { mean } \pm \text { SD }\end{array}$ & $\begin{array}{c}\text { DBH } \\
\text { mean } \pm \text { SD }\end{array}$ \\
\hline Alder & $19.6 / 64.9 / 15.5$ & $114 \pm 39$ & $52.13 \pm 18.54$ \\
Ash & $18.3 / 56.8 / 24.9$ & $75 \pm 36$ & $38.53 \pm 18.16$ \\
Birch & $24.3 / 52.6 / 23.1$ & $79 \pm 34$ & $45.97 \pm 14.59$ \\
Linden & $18.8 / 61.3 / 20.2$ & $81 \pm 40$ & $36.83 \pm 16.51$ \\
Maple & $28.4 / 49.7 / 21.9$ & $75 \pm 30$ & $35.01 \pm 15.11$ \\
Oak & $19.1 / 47.8 / 33.1$ & $90 \pm 52$ & $43.65 \pm 23.28$ \\
Spruce & $19.3 / 64.2 / 16.6$ & $102 \pm 47$ & $42.82 \pm 19.57$ \\
\hline
\end{tabular}

we were most interested in minimizing the Type I error and, therefore, providing more conservative evaluation of differences between condition classes.

The DBH variable was represented by two or three classes, depending on the DBH distribution of each tree species. We considered species-specific routines to divide DBH distributions as a valid tool to form DBH classes, since no statistical comparisons between DBH classes of different tree species were made during the analyses. Our strategy in diving DBH distribution into classes was to identify different size cohorts and, at the same time, to avoid classes with low $n$ ( $<100$ trees). We did not use percentiles in dividing DBH distribution into classes for three main reasons. First, despite the fact that the statistical properties of the initial distributions were indeed different, we intended to analyze classes which would be as similar as possible across all species studied. As a result of our classification, we established four different classification schemes. Secondly, a formal percentile-based approach would create classes with class borders located at single $\mathrm{cm}$ (and not at the start of each $10 \mathrm{~cm}$ on the dbh axis), which unnecessarily complicate the data representation. Finally, our preliminary analyses indicated that the results are not affected by the selection of class identification methods. For ash and birch, the two classes were $1<30$ and $2 \geqslant 30 \mathrm{~cm}$. For alder, two classes were established: $1<40$ and $2 \geqslant 40 \mathrm{~cm}$. For small-leaved linden, maple and spruce the following classes were used: $1<20,2-20-39$ and $3-$ $\geqslant 40 \mathrm{~cm}$. For oak, the three classes were $<30,30-59$ and $\geqslant 60 \mathrm{~cm}$. We did not consider age as an independent factor since preliminary analyses revealed a strong linear correlation between DBH and age. Age data are nevertheless reported here to set a discussion of mortality rates in a successional perspective.

Besides the impact of single independent factors, we also studied two-way factor interactions. To compare a single pair of mortality rates we used a two-sided $t$-test for independent samples, calculated as

$$
t=\frac{\sqrt{\frac{N_{1} N_{2}}{N_{1}+N_{2}}}\left(p_{1}-p_{2}\right)}{\sqrt{(p q)}},
$$

where

$$
p=\frac{p_{1} N_{1}+p_{2} N_{2}}{N_{1}+N_{2}} \text { and } p=1-q
$$

$N_{\mathrm{i}}$ and $p_{\mathrm{i}}$ are the sample size and the mortality rate in compared populations $(i=1$ or 2$)$, respectively.

\section{RESULTS}

The average age of tree populations in the park was centered around $100 \mathrm{y}$ (Tab. I). The differences among each pair 
Table II. Annual mortality rates for main tree species inventoried in the Oranienbaum Park and rates available from other studies. $n$ in the 3 rd column refers to the number of trees in each condition class. Rates are given for each condition class (5th column). The rate for condition class 3 is given in brackets to indicate that these trees were not included in the discriminant analyses. For each tree species, the difference between crown condition classes I and II was significant at, at least, $p=0.02$.

\begin{tabular}{|c|c|c|c|c|c|c|c|c|}
\hline Species & $\begin{array}{c}\text { total } n \\
\text { (this study) }\end{array}$ & $\begin{array}{c}n \\
\text { (this study) }\end{array}$ & $\begin{array}{c}\text { Overall mortality rate, } \\
\% \text { (this study) }\end{array}$ & $\begin{array}{l}\text { Mortality rate, } \\
\% \text { (this study) }\end{array}$ & Wolf, 2004 ${ }^{1}$ & $\begin{array}{l}\text { Ozolincius et al., } \\
2005^{2}\end{array}$ & $\begin{array}{l}\text { Monserud \& } \\
\text { Sterba } 1999^{3}\end{array}$ & $\begin{array}{l}\text { Tuhus, } \\
1995^{4}\end{array}$ \\
\hline Alder & 763 & $401 / 317 / 45$ & 1.6 & $1.2,2.0,(4.9)$ & 0.5 & $0.4-0.8$ & - & - \\
\hline Ash & 787 & $391 / 366 / 30$ & 1.7 & $1.5,1.9,(7.1)$ & 0.9 & $0.1-1.0$ & - & - \\
\hline Birch & 593 & 366 / 193 / 34 & 2.7 & $2.3,3.7,(9.3)$ & 1.2 & $0.2-0.4$ & - & $0.1-0.3^{5}$ \\
\hline Linden & 4184 & $2669 / 1472 / 43$ & 0.8 & $0.6,1.2,(3.9)$ & 0.5 & - & - & - \\
\hline Maple & 2252 & 1169 / 985 / 98 & 1.1 & $1.5,2.1,(8.5)$ & - & - & - & - \\
\hline Oak & 1534 & 804 / 701 / 29 & 1.0 & $0.9,1.2,(3.9)$ & 0.2 & $0.1-0.4$ & $0.6(0.1-1.4)$ & - \\
\hline Spruce & 1151 & $679 / 440 / 35$ & 1.6 & $1.3,2.0,(4.7)$ & - & $1.3-1.6$ & $0.9(0.4-1.4)$ & $<0.1-0.1$ \\
\hline
\end{tabular}

${ }^{1}$ Rates are for Carlsberg and Lime compartments combined.

${ }^{2}$ Mortality rates were obtained using a non-exponential version of the rate calculation formula (Ozolincius et al., 2005). Data range of mortality rates for different Kraft crown condition classes.

${ }^{3}$ Data represent the range of mortality rates among different dbh classes $(<5->50 \mathrm{~cm})$.

${ }^{4}$ Data represent the range of mortality rates among coniferous- vs. hardwood-dominated stands.

${ }^{5}$ Rate presented is for birch and aspen (Populus tremula L.) combined.

of average population ages were within one SD of the respective age distribution. Annual mortality rates for trees in condition classes 1 and 2 varied from $0.8 \%$ (small-leaved linden) to $2.7 \%$ (birch), with the rates of other tree species being within 1.0 and $1.7 \%$ (Tab. II). Pair-wise comparison of mortality rates showed that significant differences were associated with only two species - birch and small-leaved linden. Small-leaved linden had a significantly lower mortality rate than ash $(1.7 \%$, $p=0.021)$, alder $(1.6 \%, p=0.034)$ and birch $(p<0.001)$. The mortality rate of birch was significantly higher than the rate of maple $(1.1 \%, p=0.005)$ and oak $(1.0 \%, p=0.004)$. No significant differences were found between spruce (mortality rate of $1.6 \%$ ) and any other species. For each species studied, mortality rates were significantly different between trees in condition classes 1 and 2 , with $p$ staying below 0.02 in pairwise comparisons. Transition into the condition class 3 led to a more than two-fold increase in the mortality rate, as compared with the condition class 2 . The three largest increases were observed in maple (by 6.4\%), birch (by 5.5\%) and ash (by $5.2 \%$ ). The increase was smallest in small-leaved linden, oak and spruce (by 2.7\% for all three species). Although trees in the condition class 3 had notably higher mortality rates (Tab. II), the small number of class 3 trees did not allow us to detect significant differences between that class and class 2 trees for any species, except maple $(p<0.001)$.

General discriminant analysis showed significant effects of condition class, crown shading, $\mathrm{DBH}$, and the interaction between DBH and crown shading (Tab. III). In each of the species studied, condition class, as recorded at the first inventory in 1981, was significantly associated with probability of mortality. Despite the significance of this factor, the amplitude of this effect was moderate. In all species except birch, condition class II trees had less than $1 \%$ increase in mortality in comparison with condition class I trees (Tab. I). In birch this increase equaled $1.5 \%$.
For birch, the mortality rate increased with increase in crown shading $(1.7 \rightarrow 3.0 \rightarrow 3.3 \%)$. For maple, mortality rates decreased from small to large trees $(2.1 \rightarrow 1.5 \rightarrow 1.8 \%)$. For oak and ash, mortality decreased from small to large trees: 1.5 $\rightarrow 0.5 \rightarrow 0.4 \%$ for oak and $1.8 \rightarrow 1.5 \%$ for ash. For alder, mortality was the lowest in trees with intermediate crown shading $(1.3 \%$ class 2$)$ and higher in trees with low $(2.5 \%$, class 1$)$ and high ( $1.9 \%$, class 3$)$ crown shading.

A significant interaction between DBH and crown shading was observed in ash, spruce and oak (Fig. 2). For ash, small trees with a high degree of crown shading (class 3 ) showed the highest mortality rate $(2.6 \%)$, whereas the lowest rate was observed in trees with intermediate shading of the crown (1.5\%). In contrast to this pattern, the mortality rate of larger individuals (DBH class 2) steadily decreased with the increase in crown shading $(2.3 \rightarrow 1.7 \rightarrow 1.0 \%)$. For oak, the mortality rate of the smallest trees increased with increasing crown shading $(1.1 \rightarrow 1.5 \rightarrow 2.4 \%)$, whereas the opposite trend was observed for the middle-size and large oaks (DBH class $2: 0.8 \rightarrow 0.4 \rightarrow$ $0.6 \%$; DBH class $3: 0.6 \rightarrow 0.3 \rightarrow 0.4 \%$ ). A very similar pattern was observed for spruce trees, mortality for the smallest trees intensifying with an increase in crown shading $(1.0 \rightarrow$ $1.5 \rightarrow 2.7 \%$, Fig. 2). A tendency towards lower mortality with increase in crown shading was observed for spruces in DBH classes 2 and 3 (DBH class 2: $1.9 \rightarrow 1.2 \rightarrow 0.9 \%$; DBH class $3: 2 \rightarrow 2.7 \rightarrow 1.7 \%$ ).

For the six species, the percentage of trees of each species in condition classes 1 and 2 significantly changed between the two inventories (Tab. IV). For ash, small-leaved linden and maple there was a decrease in the proportion of trees in the condition classes 1 and 2 . The opposite pattern was observed for alder and spruce. None of the significant differences in proportions exceeded $3 \%$.

Mortality rates of deciduous trees in the Oranienbaum Park were significantly higher (at least at $p=0.01$ ) than the rates 
Table III. Discriminant analysis of tree diameter, crown condition and stand density on probability of tree death among five tree species. For each analysis statistics for independent factors are followed by statistics for the 1st canonical root and the percentage of correctly classified trees. Significant factors and their combinations are highlighted with bold font.

\begin{tabular}{|c|c|c|c|c|c|}
\hline & Wilks' Lambda & $F$-value & df effect & Df error & $P$ \\
\hline Alder & & & & & \\
\hline Intercept & 0.796 & 180.920 & 1 & 706 & $<10^{-5}$ \\
\hline Crown Class & 0.991 & 6.749 & 1 & 706 & 0.010 \\
\hline $\mathrm{DBH}$ & 1.000 & 0.273 & 1 & 706 & 0.602 \\
\hline Crown shading & 0.968 & 11.700 & 2 & 706 & $<10^{-4}$ \\
\hline Crown C. $\times$ Crown shading & 0.999 & 0.494 & 1 & 706 & 0.483 \\
\hline Crown C. $\times$ DBH & 0.997 & 1.062 & 2 & 706 & 0.346 \\
\hline $\mathrm{DBH} \times$ Crown shading & 0.994 & 1.984 & 2 & 706 & 0.138 \\
\hline \multicolumn{6}{|c|}{$\chi^{2}=33.088$, Wilks' L. $=0.945, p<10^{-4}$, correct class. $2.87 \%$ (dead) and $99.80 \%$ (living) } \\
\hline \multicolumn{6}{|c|}{ Ash } \\
\hline Intercept & 0.779 & 211.298 & 1 & 745 & $<10^{-5}$ \\
\hline Crown Class & 0.993 & 5.288 & 1 & 745 & 0.022 \\
\hline DBH & 0.990 & 7.154 & 1 & 745 & 0.008 \\
\hline Crown shading & 0.996 & 1.347 & 2 & 745 & 0.261 \\
\hline Crown C. $\times$ Crown shading & 0.999 & 0.394 & 1 & 745 & 0.531 \\
\hline Crown C. $\times$ DBH & 0.999 & 0.486 & 2 & 745 & 0.615 \\
\hline DBH $\times$ Crown shading & 0.986 & 5.101 & 2 & 745 & 0.006 \\
\hline \multicolumn{6}{|c|}{$\chi^{2}=33.088$, Wilks' L. $=0.957, p<10^{-3}$, correct class. $11.11 \%$ (dead) and $97.49 \%$ (living) } \\
\hline Birch & & & & & \\
\hline Intercept & 0.661 & 281.060 & 1 & 547 & $<10^{-5}$ \\
\hline Crown Class & 0.986 & 7.571 & 1 & 547 & 0.006 \\
\hline DBH & 0.996 & 2.154 & 1 & 547 & 0.143 \\
\hline Crown shading & 0.982 & 4.923 & 2 & 547 & 0.008 \\
\hline Crown C. $\times$ DBH & 0.999 & 0.396 & 1 & 547 & 0.529 \\
\hline Crown C. $\times$ Crown shading & 0.998 & 0.623 & 2 & 547 & 0.537 \\
\hline DBH $\times$ Crown shading & 0.993 & 1.966 & 2 & 547 & 0.141 \\
\hline \multicolumn{6}{|c|}{$\chi^{2}=37.496$, Wilks' L. $=0.934, p=110^{-4}$, correct class. $44.88 \%$ (dead) and $75.08 \%$ (living) } \\
\hline Linden & & & & & \\
\hline Intercept & 0.908 & 415.379 & 1 & 4123 & $<10^{-5}$ \\
\hline Crown Class & 0.990 & 43.326 & 1 & 4123 & $<\mathbf{1 0}^{-5}$ \\
\hline $\mathrm{DBH}$ & 0.999 & 0.777 & 2 & 4123 & 0.460 \\
\hline Crown shading & 0.999 & 1.964 & 2 & 4123 & 0.140 \\
\hline Crown C. $\times$ DBH & 1.000 & 0.197 & 2 & 4123 & 0.822 \\
\hline Crown C. $\times$ Crown shading & 1.000 & 0.297 & 2 & 4123 & 0.743 \\
\hline DBH $\times$ Crown shading & 0.998 & 1.306 & 4 & 4123 & 0.266 \\
\hline \multicolumn{6}{|c|}{$\chi^{2}=96.151$, Wilks' L. $=0.977, p<10^{-5}$, correct class. $0.00 \%$ (dead) and $100.0 \%$ (living) } \\
\hline Maple & & & & & \\
\hline Intercept & 0.723 & 810.632 & 1 & 2136 & $<10^{-5}$ \\
\hline Crown Class & 0.987 & 27.572 & 1 & 2136 & $<10^{-5}$ \\
\hline DBH & 0.991 & 9.491 & 2 & 2136 & $<\mathbf{1 0}^{-4}$ \\
\hline Crown shading & 0.999 & 0.792 & 2 & 2136 & 0.453 \\
\hline Crown C. $\times$ DBH & 1.000 & 0.296 & 2 & 2136 & 0.744 \\
\hline Crown C. $\times$ Crown shading & 0.998 & 1.881 & 2 & 2136 & 0.153 \\
\hline DBH $\times$ Crown shading & 0.999 & 0.391 & 4 & 2136 & 0.815 \\
\hline \multicolumn{6}{|c|}{$\chi^{2}=53.770$, Wilks' L. $=0.975, p<10^{-3}$, correct class. $2.17 \%$ (dead) and $99.11 \%$ (living) } \\
\hline Oak & & & & & \\
\hline Intercept & 0.923 & 124.103 & 1 & 1487 & $<10^{-5}$ \\
\hline Crown Class & 0.995 & 6.786 & 1 & 14487 & 0.009 \\
\hline DBH & 0.947 & 41.308 & 2 & 14487 & $<\mathbf{1 0}^{-5}$ \\
\hline Crown shading & 0.998 & 1.178 & 2 & 1487 & 0.308 \\
\hline Crown C. $\times$ Crown shading & 0.999 & 0.997 & 2 & 1487 & 0.369 \\
\hline Crown C. $\times$ DBH & 1.000 & 0.170 & 2 & 1487 & 0.843 \\
\hline DBH $\times$ Crown shading & 0.990 & 3.689 & 4 & 1487 & 0.005 \\
\hline \multicolumn{6}{|c|}{$\chi^{2}=121.307$, Wilks' L. $=0.922, p<10^{-5}$, correct class. $7.77 \%$ (dead) and $97.49 \%$ (living) } \\
\hline \multicolumn{6}{|c|}{ Spruce } \\
\hline Intercept & 0.804 & 266.921 & 1 & 1098 & $<10^{-5}$ \\
\hline Crown Class & 0.995 & 5.635 & 1 & 1098 & 0.018 \\
\hline DBH & 0.995 & 2.589 & 2 & 1098 & 0.076 \\
\hline Crown shading & 0.999 & 0.493 & 2 & 1098 & 0.611 \\
\hline Crown C. $\times$ Crown shading & 1.000 & 0.203 & 2 & 1098 & 0.817 \\
\hline Crown C. $\times$ DBH & 1.000 & 0.062 & 2 & 1098 & 0.940 \\
\hline DBH $\times$ Crown shading & 0.984 & 4.605 & 4 & 1098 & 0.001 \\
\hline$\chi^{2}=68.311$, Wilks' L. $=0.9$ & , correct class. 15 & 1) and 93.3 & & & \\
\hline
\end{tabular}



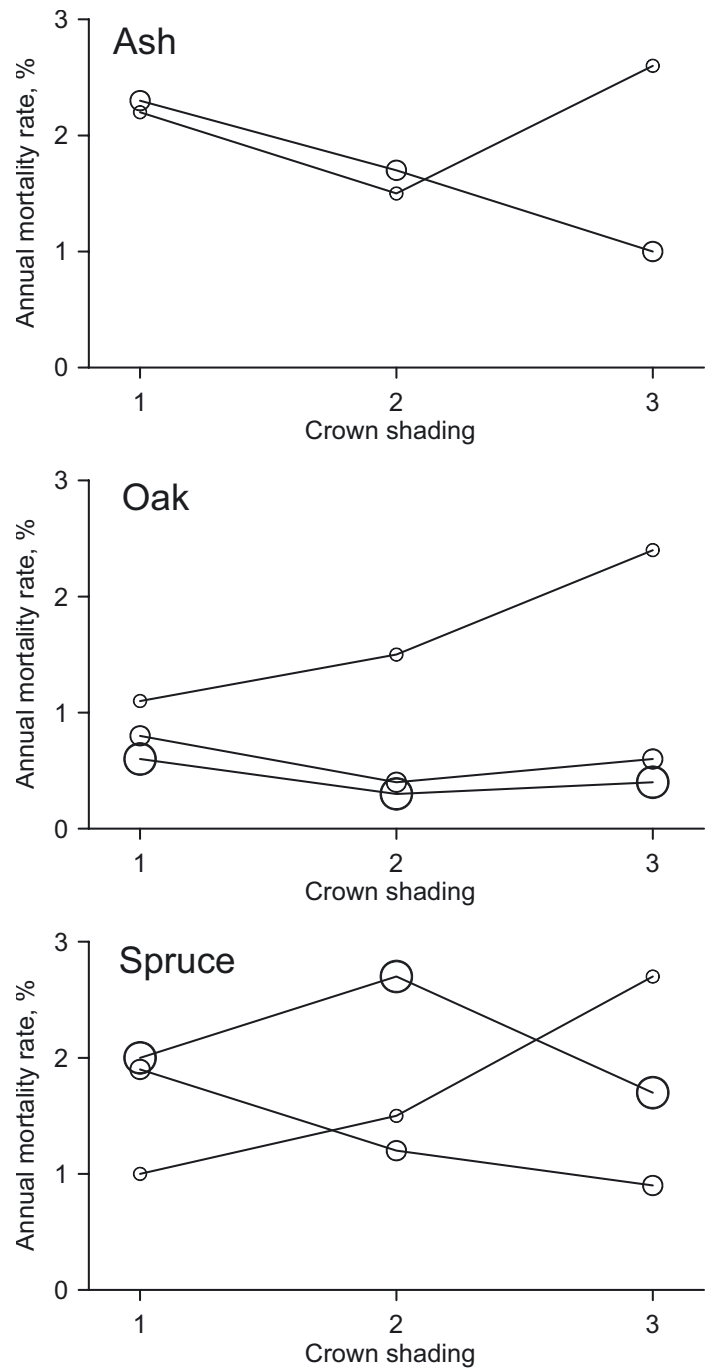

Figure 2. Relationship between tree diameter and shading of tree canopy, affecting annual mortality rates of oak, spruce and ash. Size of the symbol is proportional to the average tree size in respective DBH classes. Statistical details of each analysis are given in Table III.

reported in the studies of Ozolincius et al. (2005) and Tuhus (1995) (Tab. II). However, comparison with the only available dataset from a natural deciduous forest (Wolf, 2004) showed no significant differences between the five species in common between the two datasets. The value of $p$ stayed above 0.22 in pair-wise comparisons when only trees in condition classes I and II were considered, and above 0.18 when all condition classes were included in the analyses. The range of mortality rate variation for spruce did not significantly differ from the rate reported in Ozolincius et al. (2005) and was significantly higher (at least at $p=0.01$ ) than the rates reported in the studies of Monserud and Sterba (1999) and Tuhus (1995).

We also obtained estimates of mortality rates for eleven less abundant tree species (Appendix Tab. A), which are not analyzed in this paper, but are nevertheless provided to meet any need for such data by forest managers or modeling studies.
Table IV. Changes in the tree condition classes between two inventories (1981 and 2003) in the Oranienbaum Park. For both inventories, the percentage is based on the total number of living trees only.

\begin{tabular}{llcc}
\hline \multirow{2}{*}{ Species } & \multicolumn{2}{c}{$\%$ trees in condition classes 1 and 2 } & $p$ \\
\cline { 2 - 3 } & 1981 & 2003 & \\
\hline Ash & 96.2 & 93.4 & 0.010 \\
Alder & 94.1 & 96.6 & 0.027 \\
Birch & 94.3 & 94.2 & 0.943 \\
Linden & 99.0 & 96.9 & $<0.001$ \\
Maple & 95.6 & 92.8 & $<0.001$ \\
Oak & 98.1 & 96.2 & 0.002 \\
Spruce & 97.0 & 99.0 & 0.001 \\
\hline
\end{tabular}

\section{DISCUSSION}

The Oranienbaum Park is situated at the northern border of the European hemi-boreal zone defined by the northern distribution limits of several deciduous species (e.g. oak, maple and small-leaved linden; see Dahl, 1998). To the best of our knowledge, no detailed mortality studies have been conducted within this type of semi-natural boreal forest in Northern Europe. Both the absence of forest management in the park over at least the last half of the last century (1945-2003) and the original design of the large portion of the area as a landscape park (Gorbatenko, 2001) justify consideration of the area as one covered by semi-natural vegetation little influenced by forest management. A novelty of this study is also in the combination of a relatively large dataset (more than 11000 of single trees inventoried twice) and estimates of the light regime for each tree inventoried, typically not available in forest inventory studies (e.g. Monserud and Sterba, 1999; Ozolincius et al., 2005).

\subsection{Mortality rate and its determinants}

Over 1981-2003, tree mortality rates in the Oranienbaum Park were generally at the level of 1 to $3 \%$ annually. Although the dataset used lacks enough detail to provide definite answers about the main drivers of tree mortality, similarity in both the mortality rates among species (with the exception of the higher mortality rate for birch) and the effects of treelevel variables, suggests a rather non-species-specific pattern of mortality in the Oranienbaum Park. Thus, we did not find support for the hypothesis I, suggesting species-specific variation in the mortality rates. Lack of information on the actual causes of death precludes discussion of species- and even site-specific mortality drivers (see, e.g., Kussner, 2003). However, field observations (Dobrovolsky, 2007) indicated that in the studied area, most of the mortality events were not windrelated, implying that light conditions and competition were apparently important mortality factors.

Mortality rates of oak and small-leaved linden were consistently lower than rates of other tree species in each of the tree condition classes. This pattern likely reflects a longer lifespan and residency time in the canopy commonly reported for these 
species (Grime et al., 1988). For oak, the mortality rate obtained in our study (1.0\% annually for condition class 1 and 2 trees) was identical to the average rate of $1 \%$ reported for mature oaks growing in a wide range of habitats across Europe (Drobyshev et al., 2008). For small-leaved linden, our estimate $(0.8 \%)$ was close to the rate reported for this species in a Danish natural old-growth forest (0.5\%, Wolf, 2004). Besides the late-successional biology of these species, such relatively low mortality rates might be related to the absence of population decline (see, e.g., Sonesson, 1999; Drobyshev et al., 2007a). Interestingly enough, the mortality rates observed in the Oranienbaum Park agreed well with the data obtained in more southerly located forests (Wolf, 2004), suggesting that the intensity of natural non-dieback mortality may not significantly differ over different parts of North European deciduous forests.

Birch showed the highest mortality rate $(2.7 \%)$ and significantly exceeded the mortality rates of most of the studied species. The high mortality rate of birch might reflect a feature of birch strategy as an early-successional species with fast initial growth rates and a relatively short life span (70-120 y) (Atkinson, 1992). In the Oranienbaum Park, the birch population is approaching the upper age limit for this species (Tab. I). The observed birch mortality rate was almost identical to the rate reported from drained peatland sites in northern and central Finland (2.98\%, Jutras et al., 2003), despite considerable differences in the growth conditions between the two study areas.

The spruce mortality rate $(1.6 \%)$ was not significantly higher or lower than that of any other species. Field observations indicate that spruce is currently increasing its proportion in the park's forest canopy, likely as a result of low canopy disturbance rates limiting regeneration opportunities for less shade-tolerant species (Dobrovolsky, 2007). For spruce, significant interaction between $\mathrm{DBH}$ and crown shading indicated that mortality of small and well-shaded trees was an important contributor to overall species mortality in the park, probably due to competition effects. Similarly to the deciduous species, our estimate of spruce mortality was close to the rates reported elsewhere. Mortality of spruce saplings and mature trees in a natural old-growth forest in northern Sweden was found to be $1.8 \%$ and $0.7 \mathrm{y}^{-1}$, respectively (Jonsson et al., 2007; Lundqvist and Nilson, 2007), which agrees well with our estimates. A number of published spruce mortality rates (Monserud and Sterba, 1999; Tuhus, 1997) are, however, significantly lower than the one in this study. We attribute this difference primarily to the higher average age of the spruce population (102 y) in our study.

Despite differences in species biology (e.g. in the degree of shade tolerance and in the average longevity), alder, ash and maple revealed generally similar mortality rates for healthy and moderately healthy trees (1.2-2.0\%). For alder and ash, the observed rates were higher than in the study of Ozolincius et al. (2005), although the absolute differences were small (about $0.5-1 \%$ ).

Effects of species-specific biology on mortality and, subsequently, on the canopy turnover rate in the park is generally overridden by the general "health status" of the trees and en- vironmental conditions (e.g. amount of available light) of single trees. We base this conclusion on (1) the consistent and highly significant effect of the tree condition class, and (2) the relatively few significant differences between annual mortality rates found in this study. These results question the validity of the hypothesis I, but provide support for the hypothesis II, stressing the role of environmental factors in affecting the probability of mortality. Our analyses show that tree condition class has the highest predictive power in respect to the probability of mortality. The effect of tree condition class was observed across all species studied and for all pair-wise class comparisons. A transition from the moderately healthy trees class towards declining trees translated into a two- to fourfold increase in mortality rates, which constitutes the largest difference of all contrasts analyzed in our study. Most of these differences were, however, not significant due to the low sample size for the declining trees. Previously, crown defoliation, the major component of tree condition status as recorded in this study, was shown to increase the predictive power of mortality models (Dobbertin and Brang, 2001). In this study, we show that even relatively moderate changes in a tree's "health status" result in detectable differences in the mortality rates, given large datasets are considered.

Despite the presence of a number of highly significant factors affecting probability of tree death in each version of the discriminant analysis (Tab. III), the classification skill for dead trees was nevertheless low. Particularly, for all of the species except birch and spruce, the percentage of correctly classified dead trees did not exceed $12 \%$. We attribute such a low classification skill to the generally low mortality rates of species and a large difference in size between the classes of living and dead trees, i.e., from a statistical viewpoint, a very large proportion of trees in one of the classes of dependent discriminating variables. A similar observation about the difficulty in predicting tree species mortality was previously made by Monserud and Sterba (1999). In Austrian Forest Inventory data, size and competition variables allowed correct identification of dead trees in 25 to $44 \%$ of cases (percent correct classification). Using crown condition and social tree position while analyzing Swiss Forest Health Inventory (SFHI) data, Dobbertin and Brang (2001) achieved correct classification in 8-11\% and 21$33 \%$ of cases, depending on the method used (stochastic or deterministic classification schemes, respectively). Applying classification and regression tree methods with variables such as crown ratio, relative tree height and relative tree diameter Dobbertin and Biging (1998) correctly classified the status of 28-36\% Pinus ponderosa trees and 11-17\% of Abies concolor trees in California.

\subsection{Interaction effects on mortality rates}

For ash, maple and oak, smaller trees were subject to higher mortality rates than larger individuals of the respective species. Given DBH being a reasonable proxy for tree age, this pattern may represent a general tendency of higher mortality rates due to higher susceptibility of younger trees to environmental stresses (e.g. competition or stressful weather conditions), as is 
universally observed in closed canopy forests (Franklin et al., 1987). The average age of the trees in size class 1 varied between 31 (ash), 30 (maple) and 35 (oak) years, indicating that a large proportion of these trees were in the understory where suboptimal growth conditions likely dominated. Size of a tree, besides being a proxy for tree age, might also be indicative of a tree's vitality, e.g. its ability to compete with other individuals. The class of the smallest trees might have a higher proportion of overcompeted trees, as compared with other size classes. The higher mortality rate of such overcompeted trees might subsequently increase the mortality of the whole size class. Since precise age determination was available for only a fraction of the trees inventoried, it was not possible to assess the relative importance and interactions between size and age effects on tree mortality.

Trees with poorly exposed crowns showed consistently higher mortality rates as compared with trees with a lesser degree of crown shading. This effect was observed in tree species with various levels of shade tolerance (moderate - in spruce, and low - in oak and ash). These results support the view that competitive interaction might be the dominant mortality factor for small trees in Oranienbaum Park. A review of oak mortality rates in Europe (Drobyshev et al., 2008) suggested that its mortality rate is generally correlated with stand density. Similar results were obtained for Norway spruce (Repola et al., 2006). In that study, even a moderate thinning (22\% of the basal area) was shown to significantly reduce long-term mortality rates in mixed spruce-birch stands in eastern Finland.

For ash, oak and spruce, large trees' mortality had a tendency to decrease with increasing degree of crown shading. A possible explanation of this mortality pattern might be a higher evapotranspiration demand of larger trees in more open habitats which, compared with smaller and generally younger trees, also tend to reduce water-use efficiency. Large trees might, therefore, experience more stressful environmental conditions in more open habitats, as compared with large trees with better shaded crowns. Both spruce and oak are sensitive to drought events during their growth period (Drobyshev et al., 2007b; Vygodskaya et al., 2002). More intense air flow resulting in a higher evapotranspiration demand around more exposed trees could make trees more susceptible to water deficit and, in the long run, lead to increased mortality rates. In dense spruce plantations, where thinning has been shown to improve tree water balance and the resistance of tree radial growth to drought stresses (Laurent et al., 2003), such an interaction is unlikely. However, canopy tree density in larger portions of the Oranienbaum Park was low (below 200 trees $\cdot \mathrm{ha}^{-1}$, Dobrovolsky, 2007). Under such conditions, an overall positive effect of increased tree density on larger and older trees might be a result of increased air humidity being more important than the associated decrease in soil water availability.

Contrary to the frequently reported positive association between mortality rate and tree size in natural mixed forests (e.g. see Runkle, 2000 for data from the southern Appalachians), we did not find a consistent pattern of association of mortality rates with tree size in the Oranienbaum Park. The negative association between mortality rate and tree size in ash, maple and oak suggested that competition-related mortality was one of the dominant factors of tree mortality in the park, at least for these tree species. With no history of considerable windfalls, disease or insect outbreaks known for the park over the study period (Maximov et al., 1982), natural mortality was probably dominated by endogenous factors. For each of the tree species studied, the proportion of trees in the three condition classes was generally similar in the 1981 and 2003 inventories, indicating the absence of recent environmental stresses that could increase mortality rates in the coming decades.

The mortality rates obtained in this study were generally higher than the rates known from other European studies, including inventories of Lithuanian (Ozolincius et al., 2005) and Austrian forests (Monserud and Sterba, 1996), and a study of mixed stands in Norway (Tuhus, 1997). Since one could expect a considerable proportion of managed forests analyzed in all the above-mentioned studies, reported mortality rates were apparently affected by management history and might underestimate the intensity of natural mortality. The fact that only trees included in the 1981 inventory were revisited during the 2003 inventory and no new recruits were studied in 2003 might also explain elevated mortality rates in the park, as compared with the above-cited studies. Ignoring new recruits made the average age of the sampled tree populations higher than the average age of all trees of a species alive at the time of the 2003 inventory.

The mortality rates observed in the Oranienbaum Park were similar to the rates obtained in the studies of natural and seminatural forests. Deciduous trees in a natural old-growth forest in Denmark (Wolf et al., 2004), which did not experience any management activities over the last half of the 20th century, were not significantly different from the rates observed in the Oranienbaum Park. Our results were also very close to the estimates from other semi-natural mixed temperate forests in North America and Asia, where mortality rates of the canopy trees did not typically exceed 2\% (Franklin et al., 1987; Lin et al., 2004; Nakashizuka et al., 1992; Runkle, 1985). This points to the general similarity in the amplitude in mortality of canopy trees in temperate deciduous forests under natural conditions.

\subsection{Management implications}

The mortality rates reported in this study are apparently not affected by major environmental stresses that occurred in the recent past. The dynamics of the proportion of healthy trees (trees in the condition classes 1 and 2) in the Oranienbaum Park suggests a slight decrease in the amount of healthy trees in ash, small-leaved linden and maple, which may be explained by natural aging of tree populations. There were no signs of forest decline or increased environmental stresses, which would imply an increase in mortality rates in the near future (Drobyshev et al., 2008). A feature of the mortality pattern, important for practical forest management in the park, was a clear association between tree condition and probability of mortality, increasing two- to fourfold for trees with declining conditions. 
Despite the significant association between tree condition class and probability of mortality for all species studied, as well as significant impacts of crown shading and tree size observed for some species, our statistical models do not have enough predictive power to justify their use on the scale of single trees or even stands. Generally low mortality rates and a strong dominance of living trees in the dataset made it statistically difficult to obtain sufficiently good discrimination functions. As an example of this effect, the highest mortality rate of birch was associated with the highest percent of correctly classified cases, i.e. number of trees, which were predicted to die between 1981 and 2003 (Tab. III). In turn, the lowest mortality and the worst classification skill of the model was observed for small-leaved linden. To address such rather stochastic patterns of mortality and take advantage of available qualitative data, the forest management plan for the park should therefore consider tree mortality on above-stand spatial scales.

Thinning of stands may be considered as a tool to regulate natural mortality (see, e.g., Repola et al., 2006). However, caution should be taken in using this approach: only for the case of birch did we observe a significant effect of shading on the scale of the whole population. For the case of ash, oak and spruce, it was the interaction between size of the tree and shading which showed a significant impact on mortality rate. Particularly, small trees generally had higher probability of dying under shaded conditions. Application of thinning treatments should, therefore, be done primarily with consideration for smaller trees, and not large upper canopy individuals.

In the future, forest management of the park will likely interact with natural succession and mortality in an attempt to combine the biological, historical and recreational values of the park. Whatever the management strategy of the park, it can benefit from generally low and, apparently, endogenously controlled mortality rates. Regulating stand density though thinning treatments may help maintain existing tree populations, specifically of noble hardwoods. Given a mortality rate of $\approx 1 \%$ annually, the canopy turnover rate (Runkle, 2000) in the Oranienbaum Park would be about 100 years. Birchdominated stands in the park reveal a more dynamic canopy turnover rate of around 30-40 y. This dynamic nature of the park's forests should be addressed in the park management plans, e.g. by providing for regeneration opportunities of the species which show lack of successful recruits in the canopy (primarily oak, small-leaved linden and pine).

Acknowledgements: This project was funded by the Carl Tryggers Stiftelse för Vetenskaplig Forskning and Carl-Fredrik von Horns Foundation at the Royal Swedish Academy of Agriculture and Forestry (grants to I.D.), the Russian Ministry of Education and Science (project grant RNP.2.2.3.2.8296 to A.D. and V.N.), and a fellowship of the Swedish Institute (grant to A.D.). We are grateful to A.A. Egorov, L.B. Golovneva, D.E. Himelbrant, V.Yu. Neshatayeva and A.A. Oskolsky for participation in the tree inventory, and V.V. Gorshkov for discussions on the earlier versions of the manuscript. We thank the two anonymous reviewers, and the Associate Editor of AFS, Matthias Dobbertin, for useful comments on earlier versions of the manuscript. We thank Mireille Fortier for linguistic corrections. The study is a contribution within the program "Sustainable management in broadleaved forests".

\section{REFERENCES}

Atkinson M.D., 1992. Betula pendula Roth (B. verrucosa Ehrh.) and B. pubescens Ehrh. J. Ecol. 80: 837-870.

Blomberg P., Billqvist M., and Ivarsson K., 2004. Personliga porträtt av skånska jättar. In: Blomberg P. and Billqvist M. (Eds.), Skånska jätteträd, Naturskyddföreningen i Skåne, Lund, pp. 119-142.

Bobiec A., 2002. Living stands and dead wood in the Bialowieza forest: suggestions for restoration management. For. Ecol. Manage. 165: 125-140.

Dahl E., 1998. The phytogeography of Northern Europe: British Isles, Fennoscandia and adjacent areas. Cambridge university press.

Dobbertin M. and Biging G.S., 1998. Using the non-parametric classifier CART to model forest tree mortality. For. Sci. 44: 507-516.

Dobbertin M. and Brang P., 2001. Crown defoliation improves tree mortality models. For. Ecol. Manage. 141: 271-284.

Dobrovolsky A., 2007. Dynamics of natural mortality and tree structure in "Oranienbaum" park. ESS Reports No. 92. Southern Swedish forest research centre, SLU Alnarp.42 p.

Drobyshev I., Anderson S., and Sonesson K., 2007a. Crown condition dynamics of oak in southern Sweden 1988-1999. Environ. Monit. Assess. 134: 199-210.

Drobyshev I., Linderson H., and Sonesson K., 2007b. Temporal mortality pattern of pedunculate oaks in southern Sweden. Dendrochronologia 24: $97-108$.

Drobyshev I., Niklasson M., Linderson H., Sonesson K., Karlsson M., Nilsson S.G., and Lannér J., 2008. Lifespan and mortality of old oaks - combining empirical and modelling approaches to support their management in Southern Sweden. Ann. For. Sci. 65: 401.

Ford C.R. and Brooks J.R., 2002. Detecting forest stress and decline in response to increasing river flow in southwest Florida, USA. For. Ecol. Manage. 160: 45-64.

Franklin J.F., Shugart H.H., and Harmon M.E., 1987. Tree death as an ecological process. Bioscience 37, 550-556.

Gorbatenko S.B., 2001. Historical and architectural guide: St. Petersburg. European House Publishing, St. Petersburg. 448 p.

Grime J.P., Hudgson J.G., and Hunt R., 1988. Comparative plant ecology. Unwin Hyman, London.

Jonsson M.T., Fraver S., Jonsson B.G., Dynesius M., Rydgard M., and Esseen P.A., 2007. Eighteen years of tree mortality and structural change in an experimentally fragmented Norway spruce forest. For. Ecol. Manage. 242: 306-313.

Jutras S., Hokka H., Alenius V., and Salminen H., 2003. Modeling mortality of individual trees in drained peatland sites in Finland. Silva Fenn. 37: 235-251.

Klecka W.R., 1980. Discriminant analysis. Sage, Beverly Hills, CA.

Kussner R., 2003. Mortality patterns of Quercus, Tilia, and Fraxinus germinants in a floodplain forest on the river Elbe, Germany. For. Ecol. Manage. 173: 37-48.

Laurent M., Antoine N., and Joel G., 2003. Effects of different thinning intensities on drought response in Norway spruce (Picea abies (L.) Karst.). For. Ecol. Manage. 183: 47-60.

Lemieux C. and Filion L., 2004. Tree-ring evidence for a combined influence of defoliators and extreme climatic events in the dynamics of a high-altitude balsam fir forest, Mount Megantic, southern Quebec. Can. J. For. Res. 34, 1436-1443.

Lin Y., Hulting M.L., and Augspurger C.K., 2004. Causes of spatial patterns of dead trees in forest fragments in Illinois. Plant Ecology 170: $15-27$.

Lorenz M., Becher G., Fisher R., and Seidling W. 2000. Forest condition in Europe. Results of the 1999 crown condition survey. 2000 technical report, Geneva and Brussels, UN/ECE and EC, 86 p. 
Lundqvist L. and Nilson K., 2007. Regeneration dynamics in an unevenaged virgin Norway spruce forest in northern Sweden. Scand. J. For Res. 22, 304-309.

Maximov V.A., Savenkov P.F., and Erf E.A., 1982. Inventory description of the Lomonosov Park. Leningrad, The Head-ofiice of Cultural Affairs Committee, Executive Committee of the City of Leningrad, $36 \mathrm{p}$.

Monserud R.A. and Sterba H., 1996. A basal area increment model for individual trees growing in even- and uneven-aged forest stands in Austria. For. Ecol. Manage. 80: 57-80.

Monserud R.A. and Sterba H., 1999. Modeling individual tree mortality for Austrian forest species. For. Ecol. Manage. 113: 109-123.

Nakashizuka T., Iida S., Tanaka H., Shibata M., Abe S., Masaki T., and Niiyama K., 1992. Community dynamics of Ogawa forest reserve, a species rich deciduous forest, Central Japan. Vegetatio 103: 105-112.

Niklasson M. and Nilsson S.G., 2005. Skogsdynamik och arters bevarande. Studentliteratur. ISBN: 9789144034461.

Ozolincius R., Miksys V., and Stakenas V., 2005. Growth-independent mortality of Lithuanian forest tree species. Scand. J. For. Res. 20: 153-160.

Pacala S.W., Canham C.D., Saponara J., Silander J.A., Kobe R.K., and Ribbens E., 1996. Forest models defined by field measurements: Estimation, error analysis and dynamics. Ecol. Monogr. 66: 1-43.

Pedersen B.S., 1998. The role of stress in the mortality of midwestern oaks as indicated by growth prior to death. Ecology 79: 79-93.

Pedersen B.S., 1999. The mortality of midwestern overstory oaks as a bioindicator of environmental stress. Ecol. Appl. 9: 1017-1027.

Pestryakov V.K., 1973. Soils of Leningrad region. Lenizdat publishing house, Leningrad.

Peterken G.F., 1996. Natural woodlands. Cambridge university press, Cambridge, $522 \mathrm{p}$.

Peterson D.L. and Ryan K.C., 1986. Modeling postfire conifer mortality for long-range planning. Environ. Manage. 10: 797-808.
Repola J., Hokka H., and Penttila T., 2006. Thinning intensity and growth of mixed spruce-birch stands on drained peatlands in Finland. Silva Fenn. 40: 83-99.

Runkle J.R., 1982. Patterns of disturbance in some old-growth mesic forests of eastern North America. Ecology 63: 1533-1546.

Runkle J.R., 1985. Disturbance regimes in temperate forests. In: Pickett, S.T.A. and White P.S. (Eds.), The ecology of natural disturbance and patch dynamics, Academic press, pp. 17-33.

Runkle J.R., 2000. Canopy tree turnover in old-growth mesic forests of eastern North America. Ecology 81: 554-567.

Sonesson K., 1999. Oak decline in southern Sweden. Scand. J. For. Res. 14: 368-375.

Suarez M.L., Ghermandi L., and Kitzberger T., 2004. Factors predisposing episodic drought-induced tree mortality in Nothofagus - site, climatic sensitivity and growth trends. J. Ecol. 92: 954-966.

Tuhus E., 1997. Natural mortality of trees. Rapport fra Skogforsk. 6. Skogforsk 6/97: 1-28.

Vygodskaya N.N., Schulze E.D., Tchebakova N.M., Karpachevskii L.O., Kozlov D., Sidorov K.N., Panfyorov M.I., Abrazko M.A., Shaposhnikov E.S., Solnzeva O.N., Minaeva T.Y., Jeltuchin A.S., Wirth C., and Pugachevskii A.V., 2002. Climatic control of stand thinning in unmanaged spruce forests of the southern taiga in European Russia. Tellus Series B-Chemical and Physical Meteorology 54: 443-461.

WMO 2008: World Meteorological Organization 2008. Weather Information for St. Petersburg. WWW address http://www. worldweather.org/107/c00203.htm Accessed 2008-02-22.

Wolf A., Moller P.F., Bradshaw R.H.W., and Bigler J., 2004. Storm damage and long-term mortality in a semi-natural, temperate deciduous forest. For. Ecol. Manage. 188: 197-210.

Zhao D.H., Borders B., and Wilson M., 2004. Individual-tree diameter growth and mortality models for bottomland mixed-species hardwood stands in the lower Mississippi alluvial valley. For. Ecol. Manage. 199: 307-322. 